Димо Чешмеджиев

Пловдивски университет

dimoclio7@yahoo.com

\title{
Българите и Атон до края на XIV век
}

\begin{abstract}
Dimo, Bylgarite i Aton do kraja na XIV vek (Bulgarians in the Mont Athos Until the End of the $14^{\text {th }}$ Century). "Poznańskie Studia Slawistyczne" 10. Poznań 2016. Publishing House of the Poznań Society for the Advancement of the Arts and Sciences, pp. 53-68. ISSN 2084-3011.

In the present work, we review the question of the presence of Bulgarians in the Mont Athos region during the the middle ages. We then examine the topic of the first orthodox monastery there and the main steps in the establishment of relations of the Bulgarian lands and state with the monastic republic.
\end{abstract}

Keywords: Mont Athos; middle ages; orthodox monastery

По време на войните, които води цар Симеон (893-927) с Византия, българската граница стига много близо до Атонския полуостров почти до Солун. По времето на цар Петьр (927-969) изворите говорят за славяно-българско население много близо до полуострова. В хрисовул, издаден от император Роман II (959-963) през 959-960 г., за манастира Колову се говори за славянобългарско население $(\Sigma \kappa \lambda \alpha \dot{\alpha} \omega \nu$

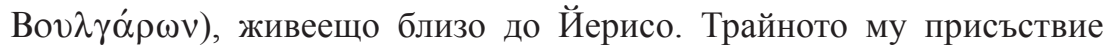
през $\mathrm{X}$ в. в района се потвърждава и от един сигилий на протоспатария Теодор от 975 г. Важно в тази насока е едно гръцко удостоверение, дадено от жителите на Йерисо на манастира Ивирон, датиращо от юни 982 г., с което се доказва, че манастирът Колову бил подчинен на Ивирон и че земята на Колову, която се намирала до Йерисо и носела българското име Градишка (Гр $\delta \delta i \sigma \kappa \alpha)$, била дадена на жителите на Йерисо под аренда за 28 години. Документьт е подписан от игумена на Великата Лавра, от епископа на Йерисо и от няколко други свидетели. Някои от тези свидетели имат славянски имена - Васил Стоимир, Власий Владко, Никола Детко, Антон Рънкавина. Един от тях се е подписал дори на глаголица. Атонските актове изобилстват 
с български топоними и антропоними (Божилов 1995b: 34-54). Тъй като българите, в сравнение с другите славянски народи, са най-бли30 до Атон, логично е да се предположи, че именно те са основали първите славянски манастири там (Иванов 1931: 21-23; Дуйчев 1963: 123; Dujčev 1965b: 491-492).

Новите публикации на документите от светогорските манастири Св. Пантелеймон (Lemerle, Dagron, Ćirković 1982) и Ксенофонт (Papachrysanthou 1986) правят отново актуален въпроса за пьрвия славянски манастир на Атон. Напоследък стана известно, че през първата половина на XI в. е имало манастир, основан от лице с ясно изразен славянски произход. Това е малък манастир, който се споменава в изворите под името Зелянос, по името на своя основател, живял найкъсно в края на X или нач. на ХІ в. След 1089 г. манастирьт изчезва от изворите за почти пет века. Според К. Павликянов манастирът е бил славянски, тъй като явно името на основателя е славянско и българско, Желян - вероятно по произход от Халкидическия полуостров или от Йерисо. Желян е бил българин и неговият манастир е бил първият славянски манастир на Атон, както и един от първите манастири на полуострова (Павликянов 1996: 17-21; Икономидис 1996: 25; Турилов, Чешмеджиев 2009: 302).

Според някои предания първият български манастир на Атон е Зограф, основан през втората половина на X в., от Георги Зограф. Манастирът очевидно е наименуван по професията на основателя си (Успенский 1880: 245-246; Божилов 1995a: 14-15; Павликянов 2005 : 17; Турилов, Чешмеджиев 2009: 302). Най-ранният документ в архива, в който се споменава името му, е продавателен акт на гръцки език от 980 г. Второ копие от акта съдържа потвърдителна приписка с подписа на йеромонах Макарий, игумен зографски: Макариє єронанахтъ:

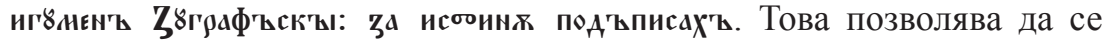
предположи, че той е съществувал в края на Х в. (основан между 972 и 980 г.) и е носел сегашното си име, Св. Георги, въпреки, че подписът на Макарий е по-късен, от 1311 г. (Иванов 1931: 526-537; Кодов, Райков, Кожухаров 1985: 8; Божилов 1995а: 15-16; Павликянов 2005: 17-18). От два акта, датиращи от 1049 и от 1051 г., засягащи един имуществен спор, може да се направи извод, че към средата на XI в. Зограф е бил гръцки манастир от средна величина, притежаващ немалко 
земя около себе си (Павликянов 2005: 23; Турилов, Чешмеджиев 2009: 302).

Интересен е въпросът, кога манастирът е станал български. В българската историография, на базата на т.нар. Сводна зографска грамо$m a$, където основаването се свързва с трима българи, идентифицирани с някои от комитопулите, както и на Разказ за зографските мъченици, обикновено се приема, че това е станало през Х в. В Разказа се казва, че дарители на манастира са били „светия цар Петър”, „великия Иван Асен” и цар Симеон. Това се отхвърля от съвременната наука с аргумента, че манастирът е основан между 972 и 980 г. и очевидно царете Симеон (893-927) и Петър (927-969) не са могли да му бъдат дарители. Остава обаче въпросът, защо точно тези български царе са включени като негови дарители? (Божилов 1995а: 17).

Според други учени няма никакви доказателства, че през X-XI в. в Зограф е имало български и изобщо монаси от славянски произход (Рараchrysanthou 1975: 93), и че той е станал български манастир едва през XIII в. (Mendieta 1972: 75). Николас Икономидис приема, че въпросът за български манастир на Атон през XI и XII в. изобщо не може да бъде поставян, доколкото българите са част от империята. Също и по времето на царете Петър (1185-1197) и Асен (1190-1196), които били възприемани като бунтовници, а не като законни владетели (Икономидис 1996: 26). Григорий Илинский приема, че Зограф е станал български между 1046 и 1049 г. (Ильинский 1908: 6). Иван Божилов използва за установяване на този факт подписите на зографските игумени под различни документи - дали те са на гръцки или на български. Въпреки че този метод е доста относителен, защото много често монаси българи и изобщо славяни са се подписвали и на гръцки, и само с монашеското си име (Икономидис 1996: 25), той единствен позволява да се достигне до някакви положителни резултати. На издаденото през 1049 г. решение на Протата, сред единадесетте подписа

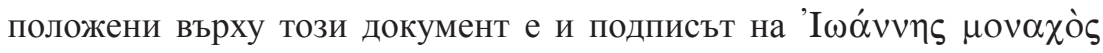

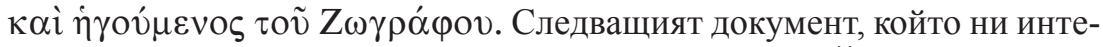
ресува, е от 1169 г. и е издаден от светогорския прот Йоан за манастира Св. Пантелеймон. Той е подписан освен от прота и от 27 игумени на атонски манастири. Сред тях на 18 място е подписът на зографския

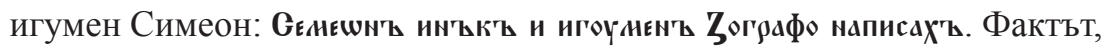


че подписът е на български показва, че игуменът е българин, тъй като всички игумени се подписват на собствения си език. Така се установява, че манастирът е станал български между 1049 и 1169 г. (Божилов 1995a: 18). Кьм това Павликянов прави корекция на базата на акта от 1051 г., когато манастирът все още е гръцки, предложеният период да се стесни между 1051-1169 г. Смята се, че Симеон, подписал акта от 1169 г., е първият българоезичен игумен на манастира (Павликянов 2005: 25; Турилов, Чешмеджиев 2009: 303).

Много отдавна в литературата е поставен въпросът, дали има връзка между България и Атон по времето на управлението на комитопулите? Положителен отговор на този въпрос обикновено се търси на базата на легендарното предание, залегнало в т.нар. Сводна зографска грамота от XVI в., наречена от М. Дринов Летопис на зографския манастир (Дринов 1845: 1). В нея е отбелязано, че той е основан в 919 г. по времето на византийския император Лъв Мъдри (Лъв VI Философ, 886-912) от трима братя българи, родом от „Първа Юстиниана, из града Лихнида" (Охрид). Те се казвали Мойсей, Арон и Йоан Селима (Кънчов 1896: 10). Били синове на „охридския цар Юстиниан” (Успенский 1880: 231). След това на Атонската гора пристигнали „цар Лъв Премъдри” със своите велможи и патриарсите на Константинопол - Анастасий и на Антиохия - Григорий, „цар Йоан Търновски" и с него търновския патриарх Теофилакт. Те подарили десет оки жълтици (Успенский, 1880: 231-232; Иванов 1931: 540-543). В тази легенда очевидно има контаминация на лица от различни епохи. Йоан Селима вероятно е идентичен със зографския игумен Йоан Селина, известен от някои грамоти от средата на XI в. - 1049 и 1051 г. Ако тази идея се приеме, това означава, че той е бил действително съществуващо лице, но е живял повече от 100 години след посочената в грамотата дата. На базата на този текст се появява и идеята, че Зографският манастир е основан именно от комитопулите (Иванов 1931: 535-539; Болутов 1961: 45; Dujčev 1965b: 493-494; Дуйчев 1972: 295-296).

Съставът, езикът и палеографските особености на грамотата показват обаче, че тя е била написона през XVI в. (Иванов 1931) или не по-рано от XVII и не по-късно от началото на XVIII в. и представлява късен фалшификат. Езикът е неиздържан и малограмотен, правописът 
е неустановен. Самият факт, че в нея се събират едновременно владетели от различни епохи: IX-X и XIII-XIV в., за да дадат правдини на манастира, е абсурден. Ако тримата братя, основали манастира, се идентифицират с част от комитопулите, те не са живели в началото на X в., а в края на X и нач. на XI в. Посочената година за основаване на манастира, 919, се разминава с годините на управление на Лъв VI, който умира през 912 г. (Божилов 1995a: 13-14; Archives de l'Athos VII 1975: 91; Турилов, Чешмеджиев 2009: 302-303).

Съществуващите „сведения” за тримата братя, основатели на Зографския манастир, както добре е показано, са изцяло легендарни и всъщност тази „връзка” с една от българските царски династии е изцяло историографска! Единствено в съвременната историография се приема, че всъщност това са комитопулите! (вж. преглед на литературата у Божилов 1995а: 13). Тази легенда вероятно възниква като отговор на някакви монашески спорове за това, кой всъщност е първият народ на Атон! Това очевидно е рожба на късната традиция, доколкото подобен въпрос в ранното и дори зрялото средновековие не е възможен (Икономидис 1996: 23).

В същото време е важно да се изтькне, че и самата Света гора по това време не представлява толкова важен фактор в живота на православните народи, в какъвто се превръща по-късно - най-рано през XI-XII в. - период, който съвпада, от българска гледна точка, с епохата на византийското владичество на българските земи. Тогава се появяват сведения за български манастир на Атон. Тук припомням мнението на Икономидис, че въпросът за български манастир не може да бъде поставян, доколкото българите са един от народите в империята, те са част от тази империя (Икономидис 1996: 26). Строго погледнато, гръцкият учен е отчасти прав - по това време наистина не може да говорим за нация и „национален” в случая манастир, а да разглеждаме проблема само етнически. Това трябва да става според тогавашните схващания. Икономидис щеше да е напълно прав, само ако в този период вече сьществуваше разграничението на национална основа. Което очевидно не може да се твърди (Божилов 1995b: 7, 110-111, с преглед на литература)! В случая ще ни интересува не това, а по-скоро фактьт, че в този период Света гора вече се превръща във фактор в съзнанието на средновековните българи, който ще се окаже важен 
в следващия период от българската история - през Второто българско царство (Каймакамова 1996: 53). Тогава Света гора ще се превърне във важен идеологически център на българската държава, макар и извън нейните предели (Stantchev 2009; Stantchev, Naumow 2014).

Историята на Второто българско царство започва в чисто идеологически план с една солунска икона на св. Димитьр (Гюзелев 2006: 36-39). Тя няма нищо общо със Света гора. Такива елементи, някъде по-реални, другаде по-хипотетични, могат да се открият по-късно. В самото начало хипотетичните преобладават, доколкото данните в изворите са оскъдни. На първо място това е въпросът около първия български архиепископ след обявяването на въстанието на Асеневци - Василий (Тютюнджиев 2007: 24-32, с по-старата литература). Макар да няма никакви преки податки, може да се зададе въпросът, дали Василий, за когото се казва само, че е бил близък на водачите на въстанието, не е бил светогорски монах преди това. Би могло да се предположи, че двамата братя, които не само въстановяват българската държава, но и българската имперска идея, са потърсили подкрепа за това в авторитета на атонското монашество в лицето на своя църковен глава?! Допълнителен, макар и доста несигурен аргумент в тази насока би могъл да бъде и фактът, че след достигането на преклонна възраст, престарелият Василий заминава за Атон, където да умре на спокойствие. Тук може да се отхвърли предпоставената теза, че българският примас бил заточен там, за да не пречи на предстоящото възстановяване на православието в Българската държава (Ников 1930: 89-90; Гюзелев 2009: 147). В средновековната българска традиция обаче няма и сянка на съмнение относно лоялността на Василий към православието (вж. примери у Kalužniacki 1899: 52-54; Kalužniacki 1901: 23, 72, 97-98; Снегаров 1954: 162-168; Иванов 1931: 419-420 424; Грашева 1982: 196; Иванова 1986: 88, 133-134, 147-148, 157, 190, $199,215,220,379)$. В същото време Василий отсъства в синодика на Българската църква, т.нар. Борилов синодик (Божилов, Тотоманова, Билярски 2010: 50).

В самото начало на XIII в. политическата ситуация на Балканите и в България значително се променя. През пролетта на 1204 г. кръстоносците от Четвъртия кръстоносен поход превземат Константинопол и основават своя империя. В този период Света гора не само запазва 
своето значение като идеологически център на православието, независимо от попадането иे под латинска власт, но и го разширява значително, доколкото Константинопол вече не се явява такъв!

През есента на същата година българският владетел Калоян сключва уния с Римската църква и българската църква попада под юрисдикцията на папата. Днес не знаем, как са се развивали отношенията между Българската държава и Атон в този период, освен един факт, който обаче не е във връзка с приетата уния, а с конкретните политически и военни отношения между българите и ромеите в Тракия след битката при Адрианопол (1205 г.). Тогава, вероятно в Солун, е създадена една легенда за убийството на цар Калоян от св. Димитър (1207 г.), записана в Чудесата на св. Димитър Солунски (Тьпкова-Заимова 1979: 17). Този сюжет има ясен атонски произход, среща се през цялото Средновековие, през Възраждането и дори до ново време на територията на всички православни народи. Десемантизиран, този сюжет навлиза в поствизантийския период и в българското изкуство. Такова изображение има и в манастира Зограф! (Божков, Василиев 1981: 211-213; Тъпкова-Заимова, Паскалева 2010: 249-263). Това очевидно представлява идеологическа контраатака срещу българското царство. Изглежда не е случайна известната контаминация, видна в т.нар. Атонски патерик, където се казва, че византийският император Михаил VIII Палеолог (1261-1282) след сключването на Лионската уния на 6 юли 1274 г., помолил „държавите на католиците” да му помогнат в борбата с българския цар „Йоан Калоян” (Турилов, Чешмеджиев 2009: 313). Като оставим настрана явния анахронизъм, доколкото по това време в България управлява цар Константин Тих Асен, а цар Калоян е бил на престола в периода 1296-1207 г. (Божилов, Гюзелев 2006: 441-448, 507-519), както и странния факт, че византийският император моли за помощ католическите държави срещу един съюзник на Рим, какъвто е цар Калоян след 1204 г., то очевидно името на българския цар Калоян е станало нарицателно сред гръцките монаси на Атон като враг. В резултат се е получила и въпросната контаминация между двама български владетели.

Значително по-ясна става картината на българо-атонските отношения по времето на цар Йоан Асен II. След битката при Клокотница през 1230 г. българският цар става покровител на Света гора. 
Известно е, че в края на март или началото на април 1230 г. българският цар посещава Света гора и дарява някои от манастирите там. Запазена е Bатопедската грамота, която свидетелства за дарение на този манастир (Ласкарис 1930; Иванов 1931: 576-577; Даскалова, Райкова 2005: 7-8, 29). Сведение за това има и в Житието на св. Петка от българския патриарх Евтимий (1375-1393). Според това житие, той покорил „,... цялата Атонска, а по-точно да кажа - Света гора” и дал хрисовули на Лаврата и Протатон, като подновил главния Протатски храм в Карея, който по-късно, през XIV в., е зографисан от Мануил Панселинос (Kalužniacki 1901: 69-70; Иванова 1986: 198; срв. Божков, Василиев 1981: 51). По същото време Иван Асен II дал дарствена грамота и на манастира Ивирон, с която потвърждава правата му над манастира Св. Богородица Елеуса при Струмица (Дуйчев 1972: 294-304; Турилов, Чешмеджиев 2009: 303).

Българският цар прави дарения и на българския манастир Зограф, спомен за което е запазен във фалшивата Сводна грамота. Цар Иван Асен II посетил манастира през последните дни на април за манастирския празник, което сведение се потвърждава и от Baтопедската грамота (Dujčev 1965b: 501; Дуйчев 1972: 295-299; Турилов, Чешмеджиев 2009: 303). За дарения на цар Иван Асен II се споменава и в Разказа за Зографските мъченици. Там се казва, че при нападението от 1275 г. били унищожени и някои от даренията на българския цар, което се приема за достоверно, въпреки спорната автентичност на паметника. Тези дарения са били потвърдени от златопечатник, който вероятно е бил унищожен от Стефан Душан, за да могат да се изземат някои правдини в полза на Хилендар (Дуйчев 1972: 300-301). Заради тази си политика на Света гора цар Иван Асен II е изобразен като ктитор в католикона на Зограф и до ден-днешен е споменаван по време на богослужение (Иванов 1931: 539; Златарски 1940: 348-349; Божков, Василиев 1981: 51, 93 сл.).

В резултат на тези дарения, при възстановяването на Българската патриаршия през 1235 г. на събора в Лампсак, присъствали и светогорски монаси, които подкрепили този акт, както свидетелства Бориловия синодик от 1211 г. На този събор бил ръкоположен и първият български патриарх от Второто царство - Йоаким I (1235-1237), също бивш атонски монах (Снегаров 1954: 162-168; Тютюнджиев 2007: 35): 


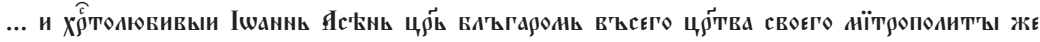

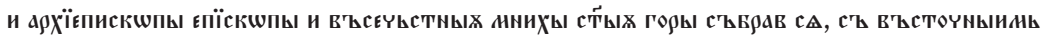

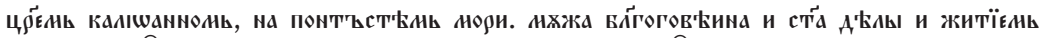

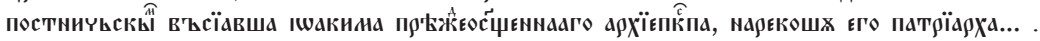
(Божилов, Тотоманова, Билярски 2010: 160).

И христолюбивият цар Асен стори същото с митрополитите, архиепископите и епископите от своето царство и с пречестните монаси от Света гора. И като се срещна при Понтийско море с източния цар Калоян, провъзгласиха за патриарх преждеосвещения архиепископ Йоаким, мъж благоговеен и свят, просиял с дела и постнически живот (Божилов, Тотоманова, Билярски 2010: 313).

За съжаление, нямаме повече сведения по тези твърде важни въпроси, но става ясно, че по това време Света гора вече се е превърнала във важен идеологически фактор за българската държава. Васил И. Златарски дори предполага, че именно от Света гора Иван Асен II е набрал подготвен клир, който да замени гръцкия в епархиите с българско население в Тракия и Македония, присъединени към България след битката при Клокотница от 1230 г. (Златарски 1940: 347-348; Цанкова-Петкова 1968: 142). Ако това предположение се приеме, а то изглежда достатъчно правдоподобно, то това означава, че българският цар е получил подкрепата на българското монашество на Света гора.

Роля за увеличаване на българското присъствие на Света гора след смъртта на цар Йоан Асен II имат и неблагополучията, които сполетели българските земи - татарските нашествия, войните за престола, селското въстание на Ивайло, нахлуванията на унгарци и сърби, накарали част от българското монашество да потърси спокойствие на Атонския полуостров (Гюзелев 1985: 70).

В архива на Зограф има запазени няколко документа от края на XIII в. - от 1270 г., от 1276 г. (или от 1291 г.), от 1279 г., 1286, 1289 (хрисовул на Андроник II, с който той потвърждава всички имоти на 3ограф), които засягат разни имотни спорове. За нас те са важни, защото показват, че в този период манастирът вече е бил наричан „манастир на българите”, факт общоизвестен на Атон и в Константинопол, както личи от актовете от 1276 и 1279 г. (Павликянов 2005: 28-32).

След сключването на т.нар. Лионска уния между Западната и Източната църква на 6 юли 1274 г. (Дринов 1971: 373-387; Острогорски 1959: 431) монасите на Зограф се обявяват против пролатинската 
и униатска политика на император Михаил VIII Палеолог и константинополския патриарх Йоан Векос. Поради тази причина, заедно с други атонски обители, на 10 октомври 1275 г. манастирът е нападнат и ограбен, а църквата и кулата му са опожарени. По време на нападението загиват 26 души, монаси и светски лица и са унищожени 193 ценни ръкописа и църковна утвар. Тези събития са описани в известния летописен Разказ за 26-те зографски мъчениции, написан въз основа на предания, съществуващи вече през втората четвърт на XV в., запазен само в един препис от Стишен пролог за септември-февруари от XVII в. по водни знаци (РНБ, Григ. Ф. 87, № 24, л. 19б-22а, Турилов, Чешмеджиев 2009: 313). Той е подложен на сериозна критика като рожба на атонските легенди и фолклор и се оспорва историческата му основа (Живојновић 1978: 147-149; Божилов 1996: 175-189; Турилов, Чешмеджиев 2009: 314; Буланин 2012: 6-9). Според някои автори става дума за текст, част от поредицата текстове, известни с общото име

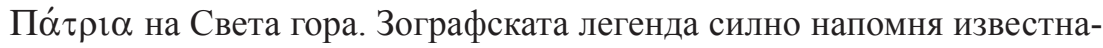
та легенда от манастира Ксиропотаму (Rigo 1988: 71-108; Божилов 1996: 179-186; Павликянов 2005: 27-28; Гюзелев 2009: 154; Турилов, Чешмеджиев 2009: 314; Буланин 2012: 6-10). Въпреки това се приема, че може би в основата на този и подобните му текстове, лежи някаква историческа истина, макар и контаминирана с много легендарни детайли и събития от други исторически епохи - латинската власт над Света гора (1204-1224), каталанските нападения в началото на XIV в., войните между България и Византия в края на XIII в. и пр. (Живојновић 1978: 148-150; Буланин 2012: 22). В нея може би се съдържа и спомен за несправедливостта извършена от инока Теодул, който преднамерено злоупотребил с името на император Михаил VIII, за да ощети българската обител (Павликянов 2005: 27-28). Тук аз искам да припомня едно друго, много вероятно, предположение на П. Ангелов, което може би най-добре обяснява събитията. Според него острата реакция на българските монаси срещу Лионската уния може би се дължи и на опита на Михаил VIII Палеолог да постави под съмнение пред събора законността на Българската патриаршия в Търново, както и на сръбската архиепископия. През 1272 г. той издава грамота за Охридския архиепископ, с която потвърждава властта му върху всички епархии, които той е притежавал след 1020 г., включително и такива, 
които след възстановяване на Българското царство преминали под юрисдикцията на Търново. Въпросът за легитимността на Търновската патриаршия (както и на сръбската архиепископия) е поставен и на самия събор, като се казва, че техния статут е установен против обичаите и каноните на църквата и без съгласието на римския папа (Ангелов 1996: 191-192; срв. Тютюнджиев 2007: 45-47).

От това време, както вече е отбелязано в литературата, започват първите опити на българските книжовници да представят Търново като център на цялата православна общност - в приписката в Търновското евангелие от 1272-1273 г., където Търново е наречен „Цариград” и приписката в т.нар. Търновски апостол от 1276-1277 г., където търновският патриарх е наречен „стълп на правоверието”, епитет обичаен за константинополския патриарх (Mošin 1955: 143; Гюзелев 2009: 154; Билярски, Илиев 1997: 181; Тютюнджиев 2007: 47).

В тази насока е много интересно сведението относно една от версиите на Разказ за зографските мъченици, достигнала до нас в руска редакция от XVI в., където се твърди, че по времето на Михаил VIII вселенският патриарх всъщност бил в Търново (Турилов 1995: 137139; Полывянный 2000: 159-160).

Малко по-късно Търновската патриаршия ще предприеме и конкретни стъпки, които показват, че тя е имала самочувствие на вселенска - през 1346 г. търновският патриарх Симеон ръкопополага срьбския патриарх, а през 1352 г. рькополага за киевски митрополит някой си Теодорит. Затова известната грамота на патр. Калист от 1355 г. (датирана напоследък в 1361 г.) като че ли се появява напълно обяснимо (Тютюнджиев 2007: 56-57). Търновски патриарх по

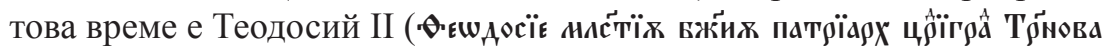

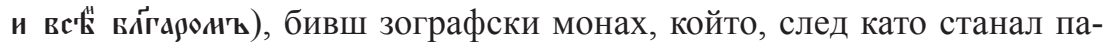
триарх, подарил на Зограф известното евангелие, писано през 1348 г. от поп Теотокий Псилица и един препис на Пандектите на Никон Черногорец (Иванов 1931: 234-235; Бурмов 1948: 6-11; Dujčev 1965b: 510; Тютюнджиев 2007: 56-58). В споменатата вече малко по-късна легенда от манастира Кастамонит (XVI в.), в която се разказва за латинското нападение над светогорските манастири от 1275 г., също се казва, че тогава седалището на вселенския патриарх било в Търново, а не в Константинопол (Гюзелев 2009: 154). 
Изглежда в тази посока трябва да се разглежда и още един интересен факт - прочутото заточение на последния български патриарх от Второто царство - Евтимий, на остров Лемнос. Както свидетелства Григорий Цамблак (Русев, Гълъбов, Давидов, Данчев 1971: 152-160), той прекарва няколко години на Света гора, в Лаврата св. Атанасий, и кулата Селина, принадлежаща на Зограф, вероятно между 1365-1370 г. (Dujčev 1971: 503-504) или по точно в периода от втората половина на 1367-1369 г. (Радић 1999: 402-403, с по-старата литература). Обикновено този акт се обяснява със съпротивата на атонското монашество срещу униатската политика на Йоан V Палеолог (Гюзелев 2009: 166-168), но като че ли по-адекватното обяснение е в посока борбата на двете църкви за надмощие и изобщо българо-византийските отношение от това време (Иванова 1986: 53; Тютюнджиев 2007: 61). По това време е в ход един от последните българо-византийски конфликти. Може би така по-лесно ще се обясни избирането на Евтимий за търновски патриарх, а не общите съображения за това, че се прочул като монах и пр. Приемайки тази теза, става по-ясно и защо примасьт-униат е наричан от патриарх Евтимий: „всечестния патриарх кир Василий” (Пространно житие на св. Петка), всечестния архиерей Божи и духовен отец на наше царско величество кир Василий” (Пространно житие на св. Йоан Рилски). Така се преодоляват и някои трафаретни обяснения, създадени под влияние на топосите в исихастките жития. За нас в случая е важно, че очевидно в тази борба между двете църкви е включено и атонското монашество!

Интересно е и едно друго наблюдение, което се отнася до XIII в., но най-вече за XIV в. и илюстрира добре значението на Света гора за българите в тази епоха. Вече стана въпрос, че още през първата половина на XIII в. един светогорски монах става Търновски патриарх - Йоаким I. След това с Атон са свързани и други бъдещи български патриарси - Теодосий II, Евтимий. Нарастналата роля на българите в това време се илюстрира и от нещо друго - българи, свързани с Атон, правят кариера и на други места. Най-впечатляващият пример в това отношение е евентуалният незаконен син на „цар Шишман” (вероятно цар Йоан Александър), станал константинополски патриарх под името Йосиф II (1416-1439), свързан със светогорския манастир 
Алипиу, където според някои свидетелства е бил монах (Дуйчев 1981: 121-126; Dujčev 1965a: 447-454; Дуйчев 1963: 122). Със Света гора са свързани и бъдещият сръбски патриарх Ефрем, руските митрополити Киприян Цамблак и Григорий Цамблак, прочутият исихаст Ромил Бдински, всички те българи по произход (Дуйчев 1963: 124-129; Божилов 1995b: 84; Каймакамова 1996: 57).

\section{Литература}

Dujčev I., 1965a, À propos de la biographie de Joseph II, patriarche de Constantinople, в: I. Dujčev, Medioevo bizantino-slavo, т. 1, Roma.

Dujčev I., 1965b, Le Mont Athos et les Slaves au Moyen âge, B: I. Dujčev, Medioevo bizantino-slavo, т. 1, Roma.

Dujčev I., 1971, Chilandar et Zographou au Moyen âge, B: I. Dujčev, Medioevo bizantino-slavo, т. 3, Roma.

Kalužniacki E., 1899, Zur älteren Paraskevaliteratur der Griechen, Slaven und Rumänen, Wien.

Kalužniacki E., 1901, Werke des patriarchen von Bulgarien Euthymius (1375-1393), Wien.

Lemerle P., Dagron G., Ćirković S., (ред.), 1982, Archives de l'Athos XII. Actes de Saint-Pantéléèmôn, Paris.

Mendieta D.E. de, 1972, Mount Athos. The Garden of the Panaghia, прев. M.R. Bruce, Berlin (Berliner Byzantinische Arbeiten, 41).

Mošin V., 1955, Ćirilski rukopisi Jugoslovenske akademije, Zagreb.

Papachrysanthou D., (ред.), 1975, Archives de l'Athos, VII Actes de Prôtaton, Paris.

Papachrysanthou D., (ред.), 1986, Archives de l'Athos XV. Actes de Xénophon, Paris.

Rigo A., 1988, La „Diègesis” sui monaci athoniti martirizzati dai latinofroni (BHG 2333) e le tradizioni athonite successive: alcune osservazioni, „Studii Veneziani” 15 , c. $71-108$.

Stantchev K., 2009, Интегриращяа и нормираща роля на Атон в литературния живот на византийско-славянската общност, в: Święta Góra Athos w kulturze Europy, Europa w kulturze Athosu, ред. M. Kuczyńska, Gniezno, c. 45-51.

Stantchev K., Naumow A., 2014, I monasteri slavi del monte Athos. Centro d'integrazione etno-culturale ed epicentri delle norme letterarie durante il medioevo, в: Kesarevo Kesarju, „Biblioteca di Studi Slavistici” 23, ред. M. Ciccarini, N. Marcialis, G. Ziffer, Firenze, c. 399-410.

Ангелов П., 1995, Отноменията между балканските държсави отразени в две грамоти за манастира Зограф от XIV в., в: Светогорска обител Зограф, т. 1, София.

Ангелов П., 1996, Образът на врага в разказа за Зографските мъчениии, в: Светогорска обител Зограф, т. 2, София. 
Билярски И., Илиев И., 1997, Папа Николай IV и българите, „Исторически преглед” кн. 5-6, с. 159-187.

Божилов И., 1985, Фамилията на Асеневии (1186-1460): Генеалогия и просопография, София.

Божилов И., 1995а, Българите във Византийската империя, София.

Божилов, И., 1995b, Основаването на светата атонска българска обител Зограф. Легенди и факти, в: Светогорска обител Зограф, т. 1, София.

Божилов И., 1996, Мъчение на зографските монаси. Легенди и факти, в: Светогорска обител Зограф, т. 2, София.

Божилов И., Гюзелев В., 2006, История на средновековна България VII-XIV в., София.

Божилов И., Тотоманова А.-М., Билярски И., 2010, Борилов синодик, София.

Божков А., Василиев А., 1981, Художественото наследство на манастира Зограф, София.

Болутов Д., 1961, Български исторически паметници на Атон, София.

Буланин Д., 2012, Антилатинский иикл Афонских легенд и болгарский Зограф, „Palaeobulgarica” бр. 1, с. 3-23.

Бурмов, А., 1948, Към документ № XXVI om „Actes de Zographou”, в: Известия на българското историческо дружество, т. 22-24, София.

Грашева Л., (съст. и ред.), 1982, Стара българска литература, т. 2: Ораторска проза, София.

Гюзелев В., 1985, Училища, скриптории, библиотеки и знания в България XIII$-X I V$ век, София.

Гюзелев В., 1995, Библиотеката на Зографския манастир през XIII-XV в., в: Светогорска обител Зограф, ред. В. Гюзелев, т. 1, София.

Гюзелев В., 2006, Чудотворната икона на св. Димитър Солунски в Търново през 1185-1186 г., в: Л. Прашков, Любен Прашков, реставратор и изкуствовед, София.

Гюзелев В., 2009, Папството и българите през средновековието, Пловдив.

Даскалова А., Райкова М., 2005, Грамоти на българските иаре, София.

Дринов М., 1845, Болгарския грамоты, Одесса.

Дринов М., 1971, Въпросът за българската и сръбската иъркви пред съдилището на Лионския събор в 1274 г., Избрани съчинения, т. 1, София.

Дуйчев И., 1963, Центры византийско-славянского общения и сотрудничества, „Труды Отдела древнерусской литературы” т. ХІХ, с. 107-129.

Дуйчев И., 1972, Приноси към историята на Иван Асен II, в: И. Дуйчев, Българско средновековие, София.

Дуйчев И., 1981, Образи на българин от XV в. във Флоренция, в: И. Дуйчев, Проучвания върху средновековната българска история и култура, София.

Живојновић М., 1978, Света гора и Лионска унија, „Зборник радова Византолошког института" т. 18, с. 141-154.

Златарски В.Н., 1940, История на българската държава през средните векове, т. 3: Второ българско ијарство, (фот. изд. 1972), София. 
Иванов Й., 1931, Български старини из Македония, София.

Иванова К., 1986, Значението на Хилендарските ръкописи за изучаването на средновековната българска книжнина, в: Кирило-Методиевски студии, кн. 3, София, с. 154-162.

Икономидис Н., 1996, Международният характер на Света гора през Средновековието, „Родина” кн. 4, София, с. 23-28.

Ильинский Г.А., 1908, Значение Афона в истории славянской письменности, „Журнал Министерства народнаго просвЊщенія” ч. 18, № 11, отд. 2, с. 6.

Каймакамова М., 1996, Света гора и българската духовна култура през Средновековието, в: Светогорска обител Зограф, т. 2, София, с. 57.

Кодов Х., Райков Б., Кожухаров С., 1985, Опис на славянските ръкописи в библиотеката на Зографския манастир в Света гора (със сътрудничеството на А. Ангелопулос и А. Каратанасис), т. 1, София.

Кънчов В., 1896, Света гора (Пътни бележки), „Библиотека” кн. XIV, XV, XVI, Пловдив.

Ласкарис М., 1930, Ватопедската грамота на ицар Иван Асена II, (Български старини XI), София.

Ников П., 1930, Църковната политика на Иван Асен II, „Българска историческа библиотека" III, кн. 3, с. 65-111.

Острогорски Г., 1959, Историја Византије, Београд.

Павликянов К., 1996, Славянското присъствие в светогорския манастир Макру през XIV и XV век, в: Светогорска обител Зограф, т. 2, с. 109-119.

Павликянов К., 2005, История на българския светогорски манастир Зограф от 980 до 1804 г. Свидетелствата на двадесет и седем неизвестни документа, София.

Полывянный Д.И., 2000, Культурное своеобразие средневековой Болгарии в контексте византийско-славянской общности IX-XV веков, Иваново.

Попруженко М.Г., 1928, Синодик изаря Борила, (Български старини, VIII), София.

Радић Р., 1999, Црквена политика Јована V Палеолога, в: Търновска книжовна школа, т. 6, Велико Търново.

Русев П., Гълъбов И., Давидов А., Данчев Г., 1971, Похвално слово за Евтимий от Григорий Цамблак, София.

Снегаров И., 1954, Неиздадени старобългарски жития, „Годишник на Духовна академия" т. 3 (XXIX), с. 151-175.

Турилов А., 1995, Малоизвестный источник по истории идеи „третьего Рима” у южных славян: Повесть о Ксиропотамском монастыре, в: Римско-константинополское наследие на Руси: идея власти и политическая практика, Москва, с. 137-139.

Турилов А.А., Чешмеджиев Д., 2009, Зографские (Афонские) преподобномученики, в: Православная энииклопедия, т. ХХ, Москва, с. 313-315.

Турилов А.А., Чешмеджиев Д., Масиель Санчес Л.К., 2009, Зограф, в: Православная эничилопедия, т. ХХ, Москва, с. 301-313.

Тъпкова-Заимова В., 1979, Култът на св. Димитър Солунски и някои въпроси, 
свързани с византийското културно влияние в балканските и славянските страни, „Studia balcanica” 14, Проблеми на балканската история и култура, c. 5-19.

Тъпкова-Заимова В., Паскалева К., 2010, Между Солун и Търново. Ощее за култа и иконографията на свети Димитър, „Годишник на Софийския Университет” т. 95 (14), с. 249-263.

Тютюнджиев И., 2007, Търновският епископат XII-XXI в., Търново.

Успенский (еп. Порфирий), 1880, Второе путешествие по Св. горе Афонской в г2. 1858,1859 и 1861 и описание скитов афонских, Москва.

Цанкова-Петкова Г., 1968, Восстановление Болгарского патриариества в 1235 г. и международное положение Болгарского государства, „Византийский временник" т. 28, с. 136-150. 